IJJM

Ilomata International Journal of Management

P-ISSN: 2714-8971; E-ISSN: 2714-8963

Vol. 1 No. 3 July 2020 pp. 121-126

https://www.ilomata.org/index.php/ijim

\title{
The Effect of Non-Performing Loans (NPL) and Capital Adequacy Ratio (CAR) on Profitability (ROA) at PT. Bank Central Asia (BCA), TBK
}

\author{
Rita Anggriani ${ }^{1}$, Puji Muniarty ${ }^{2}$ \\ ${ }^{12}$ Management Studies Program, Bima School of Economics, Bima City \\ Correspondent: puji.stiebima@gmail.com
}

Submitted : February 10, 2020 Revised : May 15, 2020 Published : July 30, 2020

\begin{abstract}
The purpose of this research is to find out and analyze whether there is an influence between Non Performing Loans and Capital Adequacy Ratio both partially and simultaneously on the Profitability (ROA) of PT. Bank Central Asia, Tbk. The approach taken in this research is associative and quantitative. The population of this study was all subjects at PT. Bank Central Asia (BCA), Tbk for 44 years, namely 1974-2018 with a total sample of 9 years, namely 2010-2018. The sampling method is a purposive sampling method. While the data analysis technique uses classical assumptions, multiple linear regression, hypothesis testing (t-test and F test) and the coefficient of determination. The results of this study prove that Non-performing Loans do not affect the Return On Assets. However, Capital Adequacy Ratio has a significant effect on Return On Asset. While simultaneously this study proves that Non-Performing Loans and Capital Adequacy Ratio affect the Return On Assets at PT. Bank Central Asia, Tbk.
\end{abstract}

Keywords: Non Performing Loan, Capital Adequacy Ratio, Return On Asset

\section{INTRODUCTION}

The credit that needs special attention is the Performing Loan. This credit requires special attention from the management to immediately determine corrective actions so that it does not become a Non-Performing Loan. Non-Performing Loans (NPL) are ratios that describe the level of a certain percentage between total current loans and loans under special attention divided by total loans granted (Abdullah, 2013: 96). Non-Performing Loans are the overall rate of return of loans provided by banks to non-bank debtors used to measure non-performing loans to total loans. the higher this ratio, the worse the quality of the bank's credit due to the greater amount of nonperforming loans and also causes a credit crisis that requires the provision of substantial benefits, decreased interest income and profits also decline in turn, (Parlan, 2014).

Another factor that determines the growth of a company is the factor of capital adequacy. According to Kasmir (2012: 232), the capital adequacy ratio (CAR) can be interpreted as a ratio used to measure capital and write-off reserves in covering credit, especially risks incurred due to interest that fails to be billed. The health of the banking system can be seen through the profitability of the bank itself. Because the main purpose of banking is to achieve maximum profitability.

Pandia (2012: 33) defines that the CAR is a bank capital adequacy ratio that shows the ability of banks to maintain sufficient capital and the ability of bank management to identify, measure, supervise and control the risks that arise that affect the amount of capital. CAR can be obtained by calculating the capital with risk-weighted assets. Riyadi (2016: 161), CAR, which is the ratio of the minimum capital requirement that must be owned by banks. At present the CAR is at least $8 \%$ of the Risk-Weighted Assets (ATMR) or added with Market Risk and Operational Risk, this 
The Effect of Non-Performing Loans (NPL) and Capital Adequacy Ratio (CAR) on Profitability (ROA) at PT. Bank Central Asia (BCA), TBK

Anggriani \& Muniarty

depends on the condition of the bank concerned. This CAR determined by Bank Indonesia refers to international regulations/standards issued by the Banking for International Settlement (BIS). This ratio is also very commonly used as an aspect of capital by following Bank Indonesia regulations.

Profitability is the ability of banks to generate or earn profits effectively and efficiently. Broadly speaking, the profits generated by the company come from sales and investment income made by the company. Profit is also often compared to other financial conditions such as sales, assets, and equity. This comparison is often called the Fahmi profitability ratio (2013: 135). Sartono (2015: 19) states that profitability is the ability of companies to earn profits concerning sales, total assets, and own capital. In this study to assess profitability using Return on Assets (ROA). ROA is a profitability ratio that is often used by companies to find out how far the assets used can generate profits. According to Hanafi (2013: 81), "This ROA ratio measures the ability of a company to generate net income based on a certain level of assets.

In general, the size of profitability in the banking industry uses ROA. Werner R. (2013: 64): "ROA reflects how much return is generated for each rupiah of money invested in the form of assets. The following are financial statement information and analysis of Non-Performing Loans (NPL), Capital Adequacy Ratio (CAR) and Profitability (ROA) ratios of PT. Bank Central Asia, Tbk Year 2010-2018.

Table 1. Growth NPL, CAR dan ROA PT. Bank Central Asia, Tbk year 2010-2018

\begin{tabular}{|l|l|l|l|l|}
\hline No & Year & NPL $(\%)$ & CAR $(\%)$ & ROA $(\%)$ \\
\hline 1 & 2010 & 1.98 & 16.61 & 3.28 \\
\hline 2 & 2011 & 1.77 & 15.00 & 3.57 \\
\hline 3 & 2012 & 1.78 & 16.47 & 3.32 \\
\hline 4 & 2013 & 1.71 & 17.50 & 3.59 \\
\hline 5 & 2014 & 2.06 & 18.93 & 3.75 \\
\hline 6 & 2015 & 1.96 & 18.55 & 3.81 \\
\hline 7 & 2016 & 2.05 & 21.77 & 3.82 \\
\hline 8 & 2017 & 1.89 & 23.03 & 3.89 \\
\hline 9 & 2018 & 1.46 & 23.95 & 3.97 \\
\hline \multicolumn{2}{|l|}{ Rata-rata } & 1,85 & 19,09 & 3.66 \\
\hline
\end{tabular}

Source : Secondary Data, processed, 2020

From the table above, the average Non-Performing Loan per year is relatively smooth. And it is under the criteria set by Bank Indonesia. Bank Indonesia's regulation regarding NPL ratios, namely the criteria for evaluating the soundness of the NPL (Non-Performing Loan) ratio, is a healthy bank with an NPL ratio below 5\%. And if the bank's ratio exceeds $5 \%$, the bank is said to be unhealthy. Furthermore, the CAR value from 2010 to 2018 increased with the highest CAR value occurring in 2018, amounting to $23.95 \%$, although it declined in 2011 . The decrease in RWA at that time did not significantly affect the CAR ratio of PT. Bank Central Asia, Tbk. The ability of banks to benefit from credit management shown in the table above is very good. This can be seen from the decrease in the number of problem loans. Thus the capital adequacy of PT. Bank Central Asia, Tbk to support assets that contain or generate risks quite well and following Bank Indonesia regulation No. 15/12 / PBI / 2013 that each bank is required to provide a minimum capital of $8 \%$ of risk-weighted assets. Return on Asset (ROA) growth in the table above fluctuates. However, the movement of the value of Return On Assets shows that profitability (ROA) is 
The Effect of Non-Performing Loans (NPL) and Capital Adequacy Ratio (CAR) on Profitability (ROA) at PT. Bank Central Asia (BCA), TBK

Anggriani \& Muniarty

regulatory requirements from Bank Indonesia, which is a minimum of $1.5 \%$. The higher profitability shows the greater ability of PT. Bank Central Asia, Tbk uses its funds from internal companies in the form of profits from the operations of the bank concerned. Thus that the growth in the value of profitability (ROA) of PT. Bank Central Asia, Tbk is inseparable from the ability of PT. Bank Central Asia, Tbk maintains that credit is not in a high NPL position to obtain the expected profitability.

The results of previous studies that support this research, namely research conducted by Julita, (2012) "The Effect of Non-Performing Loans and Capital Adequacy Ratio on Profitability (ROA) in Banking Companies Listed on the Stock Exchange" The results of this study prove that Non-Performing Loans Partial does not affect the Return On Assets (ROA), but the Capital Adequacy Ratio affects the Return On Asset (ROA). Primadewi, (2015) Faculty of Economics and Business "Effects of Capital Adequacy Ratio, Non-Performing Loans and Third Party Funds on Profitability". Based on the analysis, the results of the Capital Adequacy Ratio have a positive effect on Non-Performing Loan profitability and a negative effect on third party funds negatively affects the profitability of BPD Bali. Putrianingsih, (2016) "The Effect of Non-Performing Loans and Capital Adequacy Ratio on Profitability". on Banking Companies Listed on the IDX for the period 2010-2013. Based on the results of the study found that Non-Performing Loans negatively affect profitability. Capital Adequacy Ratio harm profitability.

\section{METHOD}

In this study using the type of associative research with quantitative approaches. Quantitative research is research that concentrates on testing theories through variables in the form of numbers and then analyzing data by statistical processes both manual and computer software. The instrument used in this study was a data table to record the values of the research variable indicators such as the number of problem loans, the number of loans extended, bank capital, RWA, total assets and profit before tax. The population of this study was all subjects at PT. Bank Central Asia (BCA), Tbk, for 44 years, namely since it was listed on the Indonesia Stock Exchange in 1974 until 2018. The sampling method used was purposive sampling, where samples were taken based on requirements made as criteria that must be met as a sample (Algifari, 2013). The criteria used as samples in this study are: Banking companies that are used as research samples have complete data (financial statements) related to the data used in this study. Based on the predetermined criteria, a sample of 9 (nine) years is obtained, from 2010 to 2018. Data collection techniques are obtained through documentation and literature study. Data analysis in this study used multiple linear regression analysis, multiple correlation coefficients, multiple coefficients of determination (R2), t-test, and F test, namely time series data. Time series data are the values of a variable sequentially according to time, for example, days, weeks, months and years. In this study using the SPPS program version 20.0. The framework of thinking in this study is as follows:

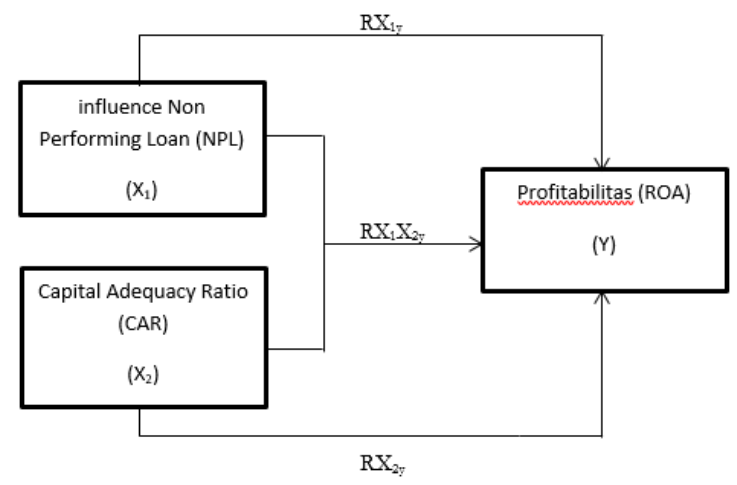


The Effect of Non-Performing Loans (NPL) and Capital Adequacy Ratio (CAR) on Profitability (ROA) at PT. Bank Central Asia (BCA), TBK

\section{RESULT AND DISCUSSION}

Table 2. Multiple Linear Regression Analysis

\begin{tabular}{|c|c|c|c|c|c|c|c|}
\hline \multicolumn{8}{|c|}{ Coefficients $^{a}$} \\
\hline \multirow[b]{2}{*}{ Model } & \multicolumn{2}{|c|}{$\begin{array}{l}\text { Unstandardized } \\
\text { Coefficients }\end{array}$} & $\begin{array}{c}\text { Standardized } \\
\text { Coefficients }\end{array}$ & \multirow[b]{2}{*}{$t$} & \multirow[b]{2}{*}{ Sig. } & \multicolumn{2}{|c|}{ Collinearity Statistics } \\
\hline & $\mathrm{B}$ & Std. Error & Beta & & & Tolerance & VIF \\
\hline (Constant) & 2.416 & .707 & & 3.418 & .014 & & \\
\hline NPL & .013 & .298 & .010 & .043 & .967 & .967 & 1.034 \\
\hline CAR & .064 & .018 & .826 & 3.509 & .013 & .967 & 1.034 \\
\hline
\end{tabular}

a. Dependent Variable: ROA

Source: SPSS output version 16.0

Based on the data above, the regression equation is as follows: $\mathrm{Y}=2,416+0.013 \mathrm{X}_{1}+$ $0.064 \mathrm{X}_{2}$

Based on the partial test results the influence of NPL on ROA was obtained t-statistic of 0.043 while the table was 2.447 and had a significant number of $0.967>0.05$. Based on the decision making criteria, it can be concluded that $\mathrm{H} 0$ is accepted ( $\mathrm{Ha}$ is rejected), this shows that there is no influence of Non-Performing Loans on Profitability (ROA) at PT. Bank Central Asia, Tbk

The influence of CAR on ROA is obtained t-statistic of 3.509 while the table is 2.447 and has a significant number of $0.013<0.05$. Based on the decision-making criteria, it can be concluded that $\mathrm{Ha}$ is accepted ( $\mathrm{H} 0$ is rejected), this shows that there is a significant influence between the CAR on ROA at PT. Bank Central Asia, Tbk

Table 3. Multiple correlation coefficient

Model Summaryb

\begin{tabular}{|l|r|r|r|r|r|}
\hline Model & $\mathrm{R}$ & R Square & Adjusted R Square & $\begin{array}{c}\text { Std. Error of the } \\
\text { Estimate }\end{array}$ & Durbin-Watson \\
\hline 1 & $.824 \mathrm{a}$ & .679 & .572 & .15992 & 2.404 \\
\hline
\end{tabular}

a. Predictors: (Constant), CAR, NPL

b. Dependent Variable: ROA

Source: SPSS output version 16.0

The multiple correlation values are 0.824 which means that the level of closeness of the relationship between the NPL and CAR variables to ROA is at a very strong level. The coefficient value of multiple linear determination is equal to 0.679 or $67.9 \%$. This means that the contribution of NPL and CAR influence on ROA has an effect of $67.9 \%$ and the remaining $32.1 \%$ is influenced by other factors not examined in this study.

Table 4. F-test

\section{ANOVA $^{b}$}

\begin{tabular}{|ll|r|r|r|r|r|}
\hline Model & & Sum of Squares & Df & Mean Square & F & \multicolumn{1}{l|}{ Sig. } \\
\hline 1 & Regression & .324 & 2 & .162 & 6.341 & $.033^{2}$ \\
& Residual & .153 & 6 & .026 & & \\
& Total & .478 & 8 & & & \\
\hline
\end{tabular}

a. Predictors: (Constant), CAR, NPL

b. Dependent Variable: ROA

Source: SPSS output version 16.0 
The Effect of Non-Performing Loans (NPL) and Capital Adequacy Ratio (CAR) on Profitability (ROA) at PT. Bank Central Asia (BCA), TBK

Anggriani \& Muniarty

Based on the F-test results in table 4.6 above the value 6.341> F-table 5.14 then supported by the results of a significant probability value of $0.033<0.05$, then $\mathrm{Ha}$ is accepted and $(\mathrm{H} 0$ is rejected), while the F-table value based on $\mathrm{dk}=\mathrm{nk}-1=6$ with a significant level of $5 \%$ is 5.14 . The calculations above show there is a simultaneous influence between NPL and CAR on ROA.

\section{CONCLUSION}

Non-Performing Loans have no significant effect partially on ROA at PT. Bank Central Asia (BCA), Tbk. This indicates that the higher the non-performing loans in bank loan management indicated in the NPL, the lower the level of bank income reflected through ROA. Capital Adequacy Ratio partially significant effect on ROA at PT. Bank Central Asia (BCA), Tbk. Based on the results of the F test that simultaneously tested and the Determination of the Adjust $\mathrm{R}$ Square Value Determination used in this study, it was found that there was an effect of NonPerforming Loans (NPL) and Capital Adequacy Ratio (CAR) simultaneously on Profitability (ROA) on PT. Bank Central Asia, Tbk.

For banking companies, especially PT. Bank Central Asia, Tbk should maintain the level of capital (CAR) it has because capital adequacy can increase its profit, namely ROA. Then it should minimize bad loans or reduce the value of NPLs, because with the decline in the value of NPLs the profit will increase, namely ROA. The next researcher is expected to be able to add other independent variables that might affect the profitability that can be generated by banking companies.

\section{REFERENCE}

Abdullah, M. Faisal. (2013). Dasar-Dasar Manajemen Keuangan. Cetakan Keempat, Penerbit Universitas Muhammadiyah Malang.

Algifari. (2013). Statistika Induktif: untuk Ekonomi dan Bisnis. Yogyakarta: Sekolah Tinggi Ilmu Manajemen YKPN.

Bungin, Burhan.(2014). Metodologi Penelitian Kuantitatif, Jakarta : Kencana.

Brigham, E.F dan Houston, J.F. (2017). Dasar-Dasar Manajemen Keuangan. Jakarta : Salemba Empat.

Cok Istri D. R. Primadewi. (2015). Pengaruh Capital Adequacy Ratio, Non-Performing Loan Dan Dana Pihak Ketiga Pada Profitabilitas. E-Jurnal Akuntansi. Universitas Udayana 12.3613 622. ISSN: 2302-8556.

Fahmi, Irham. (2013). Analisis Laporan Keuangan. Bandung : Alfabeta.

Ghozali, Imam.(2016). Aplikasi Analisis Multivariate Dengan Program (IBM SPSS). Edisi 8. Badan Penerbit Universitas Diponegoro. Semarang.

Indriantoro, N, Bambang Supomo. 2014. Metodologi Penelitian Bisnis Untuk Akuntansi \& Manajemen. Edisi 1. Cetakan ke-12. Yogyakarta: BPFE.

Julius, R, Latumaerissa. (2014). Bank dan Lembaga Keuangan Lain. Jakarta : Salempa Empat. Kasmir.(2012). Manajemen Perbankan. Edisi Revisi. Jakarta : Rajawali Pers.

Kasmir. (2015). Analisis Laporan Keuangan. Edisi Satu. Jakarta: PT Raja Grafindo Persada.

Mudrajat, K dan Suhardjono. (2011). Manajemen Perbankan Teori dan Aplikasi. Yogyakarta: BPFE.

Muhardi, Werner R. (2013) . Analisis Laporan Keuangan Proyeksi dan Valuasi Saham. Jakarta: Salemba Empat. 
The Effect of Non-Performing Loans (NPL) and Capital Adequacy Ratio (CAR) on Profitability (ROA) at PT. Bank Central Asia (BCA), TBK

Anggriani \& Muniarty

Parlan.(2014). Impact of LDR, IPR, ACA, NPL, IRR and NOP to Toward Indonesia National Private Commercial Bank's Cost-To-Income Ratio The 2nd IBEA International Conference on Business Economic and Accounting, Hongkong.

Pandia, Frianto.(2012). Manajemen Dana dan Kesehatan Ban. Jakarta : Cetakan Pertama. PT. Rineka Cipta.

Peraturan Bank Indonesia No. 15/12/PBI/2013 tentang Penilaian Tingkat Kesehatan Bank Umum. www.bi.go.id, Jakarta.

Riyadi, Selamet. (2016). Banking Assets And Liability Management, Edisi Keempat, Jakarta : Lembaga Penerbit Fakultas Ekonomi \& Bisnis, Universitas Indonesia.

Sartono, Agus.(2015). Manajemen Keuangan dan Teori Aplikasi, Cetakan Keempat, Yogyakarta: Universitas Gajah Mada.

Sofyan, M. (2019). Analysis Financial Performance of Rural Banks in Indonesia. International Journal of Economics, Business and Accounting Research (IJEBAR), 3(3), pp. 255-262.

Sofyan, M. (2019). Faktor-Faktor Yang Mempengaruhi Kinerja Keuangan BPR Syariah Di Indonesia. Sains Manajemen, 5(2), pp. 189-201.

Sofyan, M. (2019). Faktor-Faktor Yang Mempengaruhi Profitabilitas Bank Perkreditan Rakyat (BPR) di Provinsi Jawa Timur. Jurnal Inspirasi Bisnis dan Manajemen, 3(1), pp. 63-76.

Surat Edaran Bank Indonesia No.13/24/DPNP tanggal 25 Oktober 2011 tentang Sistem Penilaian Tingkat Kesehatan Bank Umum. www.bi.go.id, Jakarta.

Taswan. (2015). Akuntansi Perbankan. UPP STIM YKPN, Yogyakarta. 